DOI: 10.1515/rpp-2016-0049

Postgraduate Student, SERGIY YASHCHUK National University of Life and Environmental Sciences of Ukraine Address: 16-a Heroyiv Oborony St., Kyiv, 03041, Ukraine E-mail: sergiolife92@gmail.com

\title{
FORMING STUDENTS' PROFESSIONAL LEGAL COMPETENCY IN THE CONTEXT OF EUROPEAN UNIVERSITIES' EXPERIENCE
}

\begin{abstract}
The article deals with theoretical analysis of the educational process in European higher education institutions in the context of forming future social workers' professional legal competency. Based on the study of scientific and reference sources the author has defined the peculiarities of the educational process in the most popular higher education institutions of European Union, offering Bachelor's and Master's degrees in Social Work, namely, social and technical division of labour based on the interdisciplinary relations (theoretical and practical learning, pre-professional research constituent during placements); stipulating for a less ethnocentric understanding of social problems; training of a social worker able to skillfully provide individuals, families, organizations and communities with social support to achieve optimal social functioning in a society; analysis of aims and objectives of modern social work in the local and global context of promoting human rights and social justice; application of social work methods with a focus on client participation in the process of changing; reflection of learning and professional experience and independent learning to develop professional skills of a social worker; obtaining specialization in social programmes and projects management aimed at optimizing social integration of social risk groups, such as the disabled, and supporting individuals, groups and communities (to help realize one's potential, achieve social and economic justice, prevent one's dysfunctions); accordance of doctrinal and operative education standards that reflect a modern approach to social work - an applied social science with various principles, values, theory and practice methodology.
\end{abstract}

Key words: social work, social worker, legal competency, social science, social problems, human rights, social justice, social risk groups.

\section{INTRODUCTION}

In the European Union Masters in Social Work can conduct researches on social work; analyze aims and objectives of modern social work in the local and global context promoting human rights and social justice (Ящук, 2012); reflect the integrity of theory, practice and ethics in social work; critically evaluate the interrelation between social policy, social structures and resources and social projects design (Журавська, 2010); critically analyze the interaction between a social worker and a client and perform interventions in complicated situations; apply social work methods and emphasize client participation in the process of changing; understand the principles, methods and limitations of employees' social activities in organizations and communities; reflect learning and professional experience and continue independent learning to develop professional skills of a social worker (Капська, 2011). 


\section{THE AIM OF THE STUDY}

The aim of the article consists in revealing peculiarities of the educational process in European higher education institutions that provide curricula in Social Work in the context of forming students' professional legal competency.

\section{THEORETICAL FRAMEWORK AND RESEARCH METHODS}

Peculiarities of future social workers' professional training have been studied by S. Grushchenko, A. Kapska, G. Mykhaylyshyna, M. Yevtukh, L. Zavatska and others. The problem of realizing higher law education has been considered by P. Bilenchuk, S. Gusaryev and others. Researches on legal competency of specialists have been performed by B. Andrusyshyn, A. Guba, O. Ivaniy, Ya. Kichyk, D. Klochkova and others.

In our study we have used such research methods as analysis and generalization of empirical and theoretical statements found in professional and reference literature of different scientific directions (pedagogy, psychology, sociology, law, teaching methodology, social work, etc.) by domestic and foreign scholars.

\section{RESULTS}

In Zemaitija College, Lithuania, it takes three years to complete a Bachelor's degree in Social Work (full-time). The aim of the program is to train social service specialists, able to use the latest knowledge of social work in a complex, changing multicultural society, provide social services that allow people to participate in social life. Compulsory courses are Fundamentals of Law; Human and Children's Rights; Economy and Social Policy; Psychology of Social Work; Researches on Social Work and Data Processing; Methods of Social Work; Professional Ethics and Communication; Social Projects and Programs; Social Work in Groups; Andragogics; Fundamentals of Social Services; Psychological Health; Victimology; Prospects for Social Work; Care Basics; Social Integration and Rehabilitation (Bachelorstudies.com, 2016).

At Utena University of Applied Sciences, Lithuania, one can obtain a Bachelor's degree in Social Work in 3-4 years (full-time, part-time and evening courses). Students' skills and knowledge are evaluated by a ten-point rating system. After all the subjects have been mastered, students are to take an examination or prepare a project depending on the results of the research. The overall result may consist of several components, collected during the research (current exams, independent work, projects). An instructor defines the components of the total grade and its coefficients according to the complexity of the subject and their impact on learning outcomes. At the beginning of each term instructors inform students about the impact of each component (with percentages) for the final grade on a discipline and form the criteria for the interim grade. Learning courses (modules) and practical classes are Professional Activity of a Social Worker; Social Work with Families; Social Work and Safety in Health Care; Social Work in Organizations; Social Work with Elderly; Practical Professional Activity; Social Work within Communities; the final module: Final Professional Placement; thesis (Bachelorstudies.com, 2016).

At Vytautas Magnus University, Lithuania, one can obtain a Master's degree in Social Work in 2 years (full-time). Career prospects of graduates are the following: $\mathrm{PhD}$ in Sociology, Social Work, Education and other fields of social sciences; a position of a manager or a social worker in the field of social security, education, health care service, law enforcement agencies: social support departments in municipalities, social centers, residential institutions, preschools and community centers, NGOs, hospitals, prisons, schools, universities, colleges, social research organizations. In addition, future social workers can plan, organize and manage social services; develop and implement national and international 
social work programs and projects; conduct social researches; realize prevention programs; teach social work as a discipline; develop social workers' competences; plan, realize and evaluate cooperation with individuals, groups, families and communities (Bachelorstudies.com, 2016).

The Klaipeda University, Lithuania, offers a Master's degree in Social Work (fulltime, part-time and evening courses, 4 terms), too. Key learning outcomes are knowledge and understanding; intellectual skills; practical skills; general applied skills. A qualification level enables graduates to realize themselves in the professional field of social work; take the administrative job related to the strategy for social services development: to conduct researches and work in various social institutions that provide social services (family, community) and ensure the process of professional innovations and the strategy for teamwork. The program (an introduction to the third cycle of the research) covers 3 terms. The first term includes Networks of Social Institutions in the Community; Interdisciplinary Researches on Social and Psychological Problems; Social Work: Research Methodology. The second term involves researches on Social Policy, Technologies of Social and Cultural Work in Communities, Lithuanian Society and Policy. The third term encompasses Social Programs Planning and Management, Social Work Management, Modern Social Theories. The fourth term presupposes the study of Models for Solving Ethical Problems in Communities, Methodology of Sociological Research Quality, Human and Social Environment, Cases Management, Human Right and Social Justice (Bachelorstudies.com, 2016).

It should be mentioned that regulations on examinations, assessment and classification are based on the cumulative classification to ensure an objective assessment, students' active participation in the educational process during their study and their abilities of applying theoretical knowledge in practice.

The accumulative classification includes the final grade that consists of such interim course objectives as a test, individual work, assignments, laboratory work and final grades of exams. If a student cannot achieve a minimal grade that is defined by the interim grades, he/she is not allowed to take an examination. In order to complete the program students have to defend a thesis - a final project and/or to take final examinations (Bachelorstudies. com, 2016).

In Cyprus the University of Nicosia offers a Bachelor's degree in Social Work (full-time, part-time and evening courses). Social work consists of various complicated interactions between people and their environment. Its mission consists in providing people, groups and communities with support to realize their potential, social and economic justice to avoid different problems. The degree program takes into consideration all modern social risks and needs that doubt the relevance of a traditional policy on promoting social work and protection, cultural variety and enhancing rights ans opportunities of certain people, families, groups, organizations and communities. So, the main aim of the program is to train social workers, able to demonstrate values and professional ethics, competent for a wide profile of social work practive (BSW level). Caree perspectives of graduates are rather promising as social work is a new research field in private higher education in Cyprus (since 2011). There is a wide range of fields where Bachelors in Social Work can use their knowledge and skills in both state and private sectors as well as voluntary organizations. In particular, future social workers can work in schools, consulting centers, universities, hospitals (general and psychiatric), public centers, local authorities, enterprises, noncommercial organizations, narcological dispensaries. In addition, they can obtain a $\mathrm{PhD}$ in different field (Social Work, Psychology, Consulting, Education, Mental Health Care). Learning outcomes are the following: students are able to properly use the obtained 
theoretical knowledge and further enhance and expand it; critically evaluate, argue and express their point of view; conceptually understand legal mechanisms for preventing oppression and discrimination of certain persons, groups and communities; analyze their own decisions based on actual data; develop and enhance their self-esteem in professional activity (Капська, 2011).

In Miguel Torga Institute of Higher Education, Portugal, students can obtain a Bachelor's degree in Social Service in 7 terms (full-time). The degree program is aimed at developing students' knowledge of communication, historical factors, social and political and main trends that influence the trajectory of social work as a profession and a discipline that should be analyzed with its limits / potential / abilities; analysis of Portuguese integration in European and international space in the context of historical, political, economic, social and cultural dimensions, needs and tendencies of social service; relations between social work and social politics in terms of intervention, design, development and evaluation of political programs, projects and events; understanding of theoretical and methodological and ethical and political dimensions in the field of social work to develop, plan, evaluate, study and solve problems and needs that are emerging in modern societies, in particular, in Portrugal; strengthening of theoretical and practical training in different subject fields according to continuous pedagogical strategy, namely, in social service: observatories, workshop; work on projects in research centres - course papers; itensification of relations between academic and social, institutional and social and professional stages of scientific, pedagogical and professional activities. Career prospects involve social support, health care, local government, justice, education, psychotherapeutic and psychosocial qualification for learning (Masterstudies.com, 2016).

In Norway the University of Stavanger offers a two-year full-time Master program in Social Work, namely a European Master in Social Work with Families and Children. The program was developed by the Institutie of Lisbon University (Portugal), Gothenburg Univerisity (Sweden), the very Stavanger University and Makerere University (Uganda). The University is also proud of an active participation of 26 associated partners, 8 of which are located in higher education institutions of the countries from different continents. So, the program can be characterized as global and has a great potential to fulfill the needs for development of learning and reserch skills as well as to provide empoyment in the field of social work with children and families. It is aimed at improving knowledge and skills of those who deal with interventions for vulnerable children and marginal families. Moreover, students may study for a term in Lisbon, Stavanger or Gothenburg and work on their thesis. The program is taught in English (Капська, 2011).

At the University of Gothenburg, Sweden, one can obtain a Master's degree in Social Work and Human Rights in 2 years (full-time). The main idea of the program consists in promoting less ethnocentric understanding of social problems. It is divided into certain modules, 15 credits each. The Year 1 covers two modules, namely, Social Work and Social Support and Human Rights. They involve lectures, group work and seminars dedicated to mastering scientific literature. At the end of the year Master students are to learn Research Theories. At the same time Bachelor students may undergo social work placement instead or choose an optimal course at the faculty of social sciences. The Year 2 encompasses Social Work module, namely, Social Services Activities, Professionalization and Globalization, Poverty and International Social Work, that is based on research activities. It should be mentioned that applicants must have a command of the English language as a foreign language, at least 575 (paper) and 232 (computer) TOEFL points or 6,5 (6,0 minimum in all the sections) IELTS points, B level of Swedish upper secondary school (Gymnasieskola) (Капська, 2011). 


\section{CONCLUSIONS}

Based on the analysis of scientific and reference sources we have characterized the peculiarities of the educational process in European higher education institutions that provide degree programs in Social Work in the context of forming students' legal competency.

Thus, Lithuanian universities train a social worker, able to skillfully provide individuals, families, organizations and communities with social and legal support to cope with social problems and achieve an optimal social functioning. The obtained knowledge and skills enable the graduates to perceive social phenomena in the context of their social values and dynamics; to conduct quantitative and qualitative researches. In addition, they may obtain a specialization in social programs and projects management that are directed at optimazing a social integration of social risk groups, such as people with limited abilties. Moreover, new specialists may enhance their social and professional competency of a professional and research activity (for instance, creativity, initiative, social responsibility, e-learning).

In Cyprus social workers are supposed to deal with problems and progressive social changes as they are agents of changes in societies and catalysts in lives of certain people, families, groups and communities they serve. We have concluded that the analyzed degree program is accorded with doctrinal and operative educational standards that reflect a modern approach to social work as a social science with its own principles, values, theory and practice methodology.

In Portugal the structure of a new degree program in Social Work as a scientific field is based on the social and technical division of labour grounded on the interdisciplinary relations (theoretical and practical learning, pre-professional research component during internships).

In Norway one may observe the development of education that can provide unique knowledge and competencies for an innovative international comparison of social work with families and children (students are informed about the latest researches and practices in social work with vulnerable children and their families) and increasing employment opportunities. Furthermore, students improve their theoretical knowledge and skills as they are taught how to realize EU initiatives for preventing children from violence; obtain unique competencies needed in local and national government and non-governmental organizations, a private sector of social work and security.

In Sweden educators stipulate for Masters' ethnocentric understading of social problems in the field of social work and human rights.

Rather perspective for further researches we consider the detailed study of the educational process in higher education institutions of Ukraine, European Union, the USA that provide degree programs in Social Work in the context of forming future specialists' legal competency.

\section{REFERENCES}

1. Bachelorstudies.com. (2016). Professional Bachelor of Social Work, Social Worker, Utena University of Applied Sciences. Retrieved 12.11.2016 from : http://www. bachelorstudies.com/Professional-Bachelor-of-Social-Work-Social-Worker/Lithuania/UtenaUniversity- Of-Applied-Sciences/.

2. Masterstudies.com. (2016). European Master in Social Work with Families and Children. Retrieved 12.11.2016 from : http://www.masterstudies.com/European-Master-inSocial-Work-with-Families-and-Children/Norway/UIS/. 
3. Журавська, Н. С. (2010). Методологія проектування інтерактивних курсів на основі європейського досвіду: навчально-методичний посібник [Methodology of Interactive Courses Development Based on European Experience: Textbook]. Ніжин : М. М. Лисенко, 143 p. (in Ukrainian).

4. Капська, А. Й., Завацька, Л. М., Грищенко, С. В. (2011). Технології соиіальної роботи в зарубіжних крайнах: навчальний посібник [Technologies of Social Work in Foreign Countries: Textbook]. К. : Видавничий Дім “Слово”, 248 p. (in Ukrainian).

5. Ящук, С. П. (2012). Конституционное и международное право: совершенствование основного закона [Constitutional and International Law: Main Law Improvement]. Сучасні напрями теоретичних $i$ прикладних досліджень [Modern Directions of Theoretical and Applied Researches], Volume 18, pp. 21-22. 